\title{
Flooding: is it really getting worse:
}

Yorke, Lynda

\section{Geology Today}

DOI:

$10.1111 /$ gto. 12188

Published: 25/05/2017

Peer reviewed version

Cyswllt i'r cyhoeddiad / Link to publication

Dyfyniad o'r fersiwn a gyhoeddwyd / Citation for published version (APA):

Yorke, L. (2017). Flooding: is it really getting worse: Geology Today, 33(3), 114-118.

https://doi.org/10.1111/gto.12188

\section{Hawliau Cyffredinol / General rights}

Copyright and moral rights for the publications made accessible in the public portal are retained by the authors and/or other copyright owners and it is a condition of accessing publications that users recognise and abide by the legal requirements associated with these rights.

- Users may download and print one copy of any publication from the public portal for the purpose of private study or research.

- You may not further distribute the material or use it for any profit-making activity or commercial gain

- You may freely distribute the URL identifying the publication in the public portal ?

Take down policy

If you believe that this document breaches copyright please contact us providing details, and we will remove access to the work immediately and investigate your claim. 


\title{
Flooding: is it really getting worse?
}

\author{
Lynda Yorke, School of Environment, Natural Resources and Geography, Bangor \\ University, Bangor, LL57 2UW, Wales. L.yorke@bangor.ac.uk
}

Flooding appears to be an increasing issue in the UK, Europe and worldwide. Since 2000, the UK has experienced severe floods in York (2000), Cornwall (2004), Cumbria (2005), Hull (2007), Cumbria (2009), North Wales (2012) and UK (2013/14) (Fig. 1). These floods have occurred during the summer, autumn and winter periods, and have caused countless issues to the publics, infrastructure and the government. Based on recent events it could be said that flooding is getting worse, but is that really the case?

\section{Flood Types and Causes}

When it comes to flooding there are a few different types: riverine, coastal, pluvial, and groundwater. In the UK, over the last few years, we have experienced all these types of flooding, most notably during the winter storms of $2013 / 14$. More widely we are seeing the impacts of flooding globally, resulting is loss of life, or livelihoods, damage to infrastructure and huge economic losses. Traditionally, seasonal floods were thought of as bringers of life. They renewed the soils along the floodplains by inundating them with alluvium and they irrigated the crops for agriculture. However, we are a long way from the idyll of the River Nile during Egyptian times. Recent experiences of flooding show it can be devastating and have a lasting impact on those affected.

Whilst in the UK we may have become accustomed to seeing images of riverine flooding, where great swathes of the valley floor have been inundated by a river, submerging roads and houses, or the coastal fringe battered and flooded by storm/tidal surges, globally there are a number of different types of flooding. We can assign causes of riverine or coastal flooding to a number of mechanisms: atmospheric drivers; tectonic causes; or technological failures (Fig. 2).

Coastal flooding has been particularly devastating in recent years, both in the UK and globally. In the UK, we have seen storm surges linked to depressions and associated winter storms e.g. Aberystwyth. These surges can be doubly overwhelming if they coincide with high tides and/or high river levels, leading to estuarine flooding and inundation of coastal lowlands. In the USA, where storm surges are often associated with advancing Hurricanes, e.g. Katrina, Sandy, the impact on coastal regions has been devastating. In the case of Hurricane Katrina in 2005 the loss of coastal wetlands, a natural buffer to coastal surges, allowed coastal waters to surge into the low lying areas of New Orleans. The loss of the wetlands was precipitated by the long-term management of the Mississippi river. Progressively the river has been engineered and its floodplain disconnected from the river, this has resulted in a lack of sediment replenishment of the coastal delta and therefore a decrease in the wetlands.

Rivers draining small catchments, where their morphometry (shape) means heavy rainfall in the catchment can very quickly reach the river are at risk of flooding. Added to this can be very steep catchment slopes that aid quick run-off. The extreme flooding that happened in Boscastle in 2004 is a good example of how a small catchment, with steep slope and a narrow, confined valley bottom can lead to severe flooding in the downstream reach. 
Semi-arid rivers and rivers with narrow gorges, such as those found in the Mediterranean, are extremely susceptible to flash flooding. Ephemeral rivers that only flow at certain times of the year can quickly become torrents during the first major rain storm event. Where this occurs and the river flows through a bedrock gorge, e.g. the Aradena Gorge, Crete, the consequences can be devastating for anyone caught up in the area. Quite often where there are large ephemeral river systems exit narrow valleys or gorges, alluvial fans are formed. These can be substantial features, large enough for housing to have been built upon them. However, when a significant (i.e. low frequency, high magnitude) flood occurs this can lead to major destruction by the flood waters as the swollen river ploughs out across the alluvial fan.

Rising water levels in lakes can lead to inundation of the lake foreshore and beyond. Lakes may be stores for significant quantities of water but they can reach capacity and then overspill onto their floodplain. The Great Lakes, USA, often experience raised water levels following the spring melt of snow.

Wherever there are man-made dams and reservoirs this is potential for a flood to occur. The causes of these floods can be related to poor design of the dam or inherent geological issues either not accounted for during the planning stage or misunderstood. For example, in 1963 the Vaiont dam in Italy was overtopped by a flood (seiche) wave that went on to devastate towns and villages downstream, but without destruction to the dam itself. The cause was related to the local geology of the valley in which the reservoir was hosted. The increase in pour water pressure in the surrounding rock of the reservoir lead to failure of the bedrock, resulting in a landslide into the reservoir causing a seiche wave that was large enough to exceed the top of the dam and run-out down the river valley. In 1976, the Teton Dam was under construction in Idaho, USA. However, there were geological issues related to the bedrock, which allowed water to seep around and beneath the earthen dam structure, which then became hydraulically weakened and unable to hold back the river waters. Thus, what started as three small springs in the dam ended in a major down valley flood event causing death and destruction to several communities along the Snake River.

\section{Floods, Weather and Climate}

Atmospheric causes of flooding in northern Europe have been linked to unstable weather patterns. The position and pattern of the jet stream across the North Atlantic affects which air masses are dominant, and therefore whether we (northern Europe) experience colder, drier winters or wetter, milder summers (Fig. 3).

The North Atlantic Oscillation Index (NAOI) is a large-scale oscillation of air masses between the Azores (subtropical) High and Icelandic (subpolar) Low in the North Atlantic. A sea-surface pressure gradient exists between the air masses, which oscillates in strength between the Azores and Iceland. The NAOI can exist in two phases: positive or negative. A Positive NAOI occurs when there is a strong Azores High and a deep Icelandic Low, whereas a negative NAOI exists when there is a week upwind pressure gradient between the two. Both phases influence the intensity and location of the North Atlantic Jet Stream and storm tracks over the North Atlantic into Europe, and in the modulation of zonal and meridional air masses that transfer heat and moisture.

A positive NAOI results in a strong Meridional flow in air pressure over the North Atlantic, with the jet stream assuming a north-south (peak-trough) pattern, drawing a contrast between colder, northern air and milder, southern air. The UK tends to experience strong westerlies that draw in milder, moist air. Winters tend to be wetter across Iceland, the UK and Scandinavia during this phase. These stronger 
westerlies are associated with more northerly storm tracks, and can cause increased winter precipitation leading to flooding in northern and western parts of the UK. Positive summer NAOI can lead to blocking highs developing that result in hot, dry summers which can generate flash floods. In contrast, a negative NAOI is characterised by a weakened pressure gradient, with the jet stream is moving in a simple west-east pattern, i.e. zonal flow. These weakened westerlies are associated with reduced precipitation but colder winter temperatures across northern Europe.

Looking at the last 250 years of weather, the Little Ice Age period shows a strong relationship with a positive winter NAOI (Fig. 4). However, the NAOI has oscillated throughout this time period, and it can be shown that negative phases have been experienced since the 1930s. The pattern that has emerged from daily precipitation records between 1961 and 2000 is that rainfall has become more intense during winter and reduced during the summer months. Since 2000 , this pattern has reversed so we have seen wetter summers but fewer heavier winter rainfall events. Thus, it is not surprising that there is a perception that the start of this century has seen a greater increase in the incidences of flooding. In fact, the UK has experienced the wettest, stormiest winters since the early part of the $20^{\text {th }}$ century, with persistent heavy rainfall, strong winds, high tides and storm surges appearing to continually affect the country in recent years.

\section{Flood Magnitudes and Frequencies}

Riverine floods have been recorded through documented observations, flood height markers, gauged flow records and from sedimentological and geomorphological data. Together these data have provided a partial record of flooding that can, where sedimentological and geomorphological data exist, extend back a thousand or more years. However, generally the dataset of peak river flows is restricted to gauged records that only exist for some rivers for the last 30-40 years (Fig. 5). Thus, we can determine what the largest magnitude floods were and what their frequency of occurrence is for based on the length of the record. However, the time period over which the flood record was observed/recorded can have a major effect on the prediction of the largest floods for a river. Thus, the largest flood to have occurred during a 40-year period may represent a 1 in 50-year flood or it could represent a 1 in 200-year event. The behaviour of flooding is timeframe dependent. By examining short-term data, it could indicate that recent flooding is unprecedented, however, ignoring historical data or longer-term records may actually show that recent flooding is not exceptional and is well within what has been experienced in the past. Of course, the record is only as good as the available data, but short-term records will fail to capture flood variability.

In addition to the length of record this needs to be tempered by the fact that the period over which the record exists can be affected by a number of other factors. For example, what was the land-use in the catchment at the time, how has that now changed and how does it affect run-off and river flows. Thus, calculated flood magnitudes may be unreflective of current flood magnitudes because the flood occurred under different land-use regime. Catchment characteristics influenced by antecedent conditions, can affect run-off. Thus, prolonged rainfall or a prolonged dry period will affect the soil moisture content, which affects the ability to infiltrate rainfall. Both soil moisture deficit and soil moisture exceedance conditions will lead to greater run-off and possibly higher in-channel flow. Finally, when the data was recorded can affect the reliability of the record. If the record of highest river flows coincided with either a particularly wet or dry climatic phase, then the generated flood magnitudes and calculated return periods will be skewed by this factor. Thus, there is a large amount of uncertainty associated with flood magnitude and frequency datasets based on the reasoning given here, hence there is a need to evaluate all available data sources. 


\section{Flood Histories}

Is flooding getting worse? In order to answer that question we need to look at the long-term record of flood events. What long-term monitoring and datasets reveal is that there are clustering of flood events (Fig. 6). Over the last 300 years, the UK has experienced both flood-rich (many episodes of flooding) and flood-poor (fewer) periods. Most research has been carried out in small upland catchments in northern and western Britain. Flood-rich periods all coincided with positive phases of the NAOI, where intense summer storms tend to be generated. Certainly over the last 30-50 years it appears that he UK has seen an increasing trend for flooding, with a pattern of clustering of the worst events.

Long-term data would suggest that there is no evidence for an increase in flood magnitude over the last century. In fact, when recent peak flood events are ranked in order of size, they do not appear amongst the highest within the available record. However, what the UK has been experiencing with recent winter rainfall events is exceptional amounts of precipitation and run-off, but the magnitudes of these flood events are not generally outstanding. Flooding events over the last twenty years have been either riverine and/or coastal surges, however, neither have been particularly unusual until the winter of 2013/14 when the extent, frequency and severity of flood events throughout the winter was extraordinary.

Thus, is recent flooding a consequence of a long-term trend or short-term variability? The debate as to whether recent incidences of flooding are a consequence of $21^{\text {st }}$ century climate change is still subject to debate. We do not have the data to fully answer that question. Current thinking would suggest that we have experienced more variability in our weather and unusual patterns that can be linked to perturbations in the intensity and location of the jet stream across the North Atlantic. This can be influenced by a wide-range of potential climatic drivers. Finally, non-stationarity in our flood records can emerge through a number of factors, such as the interactions between hydrological and geomorphological effects. Together these can present a less than clear view of our flood history and the likelihood of future floods with a particular magnitude and frequency.

The relationship between weather systems, types of weather and flood events has been investigated. Results indicate that zonal systems are associated with the highest magnitude flooding. However, this can vary spatially. Research in the Tyne Valley, northeast England, indicates that there are spatial differences across the UK, with eastern Britain enduring severe flooding under a meridional system, with moderate floods linked to zonal systems. However, meridional systems are associated with blocking highs and intense summer rainfalls. Equally, this pattern of variability is repeated across Europe, though generally zonal systems were found to be dominantly associated with the worst flooding episodes. This relationship can be further complicated by the NAO and how negative or positive phases influence weather types and air mass circulations. In addition, regional climatic variability and catchment specific characteristics are important for controlling flood frequency, and because of these factors flooding episodes are not always synchronous. Finally, links between weather types and flooding cannot be substantiated for all UK regions, but the types of weather likely to be encountered can help predict the likelihood of a high flow/flood event but weather types cannot be used to predict the likelihood of an extreme event occurring. 


\section{Flood Management and Mitigation}

There can be no argument that states flooding is not a problem. However, the approaches to managing and mitigating the hazard that flooding presents is subject to a much greater debate. Whilst traditionally the approach has been to 'hard' engineer the rivers or the coast and their floodplains to protect people and properties through in-channel concrete structures, there has been a move away from such approaches in recent years. This is largely driven by the realisation that these solutions are not financially viable, and crucially they do not protect the neighbouring river reaches or coastline. Working against the physical characteristics of the river or coastline by trying to control it has made the problem of flooding worse, i.e. over-deepening of river beds, transferring coastal erosion further down the coast, which increase flooding vulnerabilities in those areas. Additionally, so-called flood protection structures give those living nearby a false sense of security, leading to a lack of preparedness when flood waters overcome the structure. However, there is now a movement for working with nature to tackle to the flooding issue embodied in the natural flood management approach.

These new approaches take a system wide view of the river or coastline, and look to utilise natural solutions to mitigate floods. These ideas are more clearly developed in the UK for riverine flooding than coastal, but within agencies, communities and government there is a clear emphasis on developing natural and alternative solutions to 'hard' engineering. Whilst flooding is an on-going threat to those in vulnerable areas, solutions that aim to slow the flow or make room for water are being trialled in many UK catchments, e.g. Belford, Northumberland. Solutions are more likely to be sustainable when responses are no-longer reactionary.

\section{Conclusion}

Flooding is the UK's most significant hazard and biggest threat to livelihoods. Climate change adds an extra layer of uncertainty to the problem and future predictions are likely to be difficult due to a lack of data and evolving scenarios. Based on the available data, we are experiencing a flood-rich period but the extent to which they are more extreme than those in the past is still very much an unknown because of the paucity of data as outlined earlier.

What is certain is that we are significantly more vulnerable to and affected by floods because of how our towns and cities have developed. There is a significant amount of our infrastructure that is built on riverine or coastal floodplains, putting people and properties at risk of flood inundation. This can be further compounded by the lack of connected planning and management between all parts of the catchment. The future management of flooding lies in avoiding knee-jerk responses to events and instead investing in long-term integrated management programmes that address the problem from the catchment rather that at-a-site. Lessons need to be learned from how rivers have been managed and mis-managed in the past. There needs to be greater connectivity between the landscape and the river, but also between scientists, communities, planners and governments if a sustainable response to flooding is to be developed. 


\section{Suggestions for further reading}

Fowler, H.J., Kilsby, C.G., 2002. Precipitation and the North Atlantic Oscillation: A study of climate variability in Northern England. International Journal of Climatology 22, 843-866.

Gregory, K.J., 2006. The human role in changing river channels. Geomorphology 79, 172-191.

Jones, A.F., Lewin, J., Macklin, M.G., 2010. Flood series data for the later Holocene: available approaches, potential and limitations from UK alluvial sediments. The Holocene 20, 11231135.

Macklin, M.G., Rumsby, B.T., 2007. Changing climate and extreme floods in the British uplands. Transactions of the Institute of British Geographers 23, 168-186.

McLean, L., Beevers, L., Waylen, K.A., Wright, G., Wilkinson, M., 2015. Learning from community led flood risk management., CREW Report CD2014-12.

Mudelsee, M., Börngen, M., Tetzlaff, G., Grünewald, U., 2003. No upward trend in the occurrence of extreme floods in central Europe. Nature 425, 166-169.

Macdonald, N., Phillips, I.D., Mayle, G., 2006. Spatial and temporal variability of flood seasonality in Wales. Hydrological Processes 24, 1806-1820.

Pattison, I., Lane, S.N., 2012. The relationship between Lamb weather types and long-term changes in flood frequency, River Eden, UK. International Journal of Climatology 32, 1971-1989.

Schillereff, D.N., Chiverrell, R.C., Macdonald, N., Hooke, J.M., 2014. Flood stratigraphies in lake sediments: A review. Earth-Science Reviews 135, 17-37.

Starkel, L., 2001. Extreme rainfalls and river floods in Europe during the last millennium. Geographia Polonica 74, pp.69-80.

Werrity, A., 2002. Living with uncertainty: climate change, river flows and water resource management in Scotland. The science of the total environment 294, 29-40. 


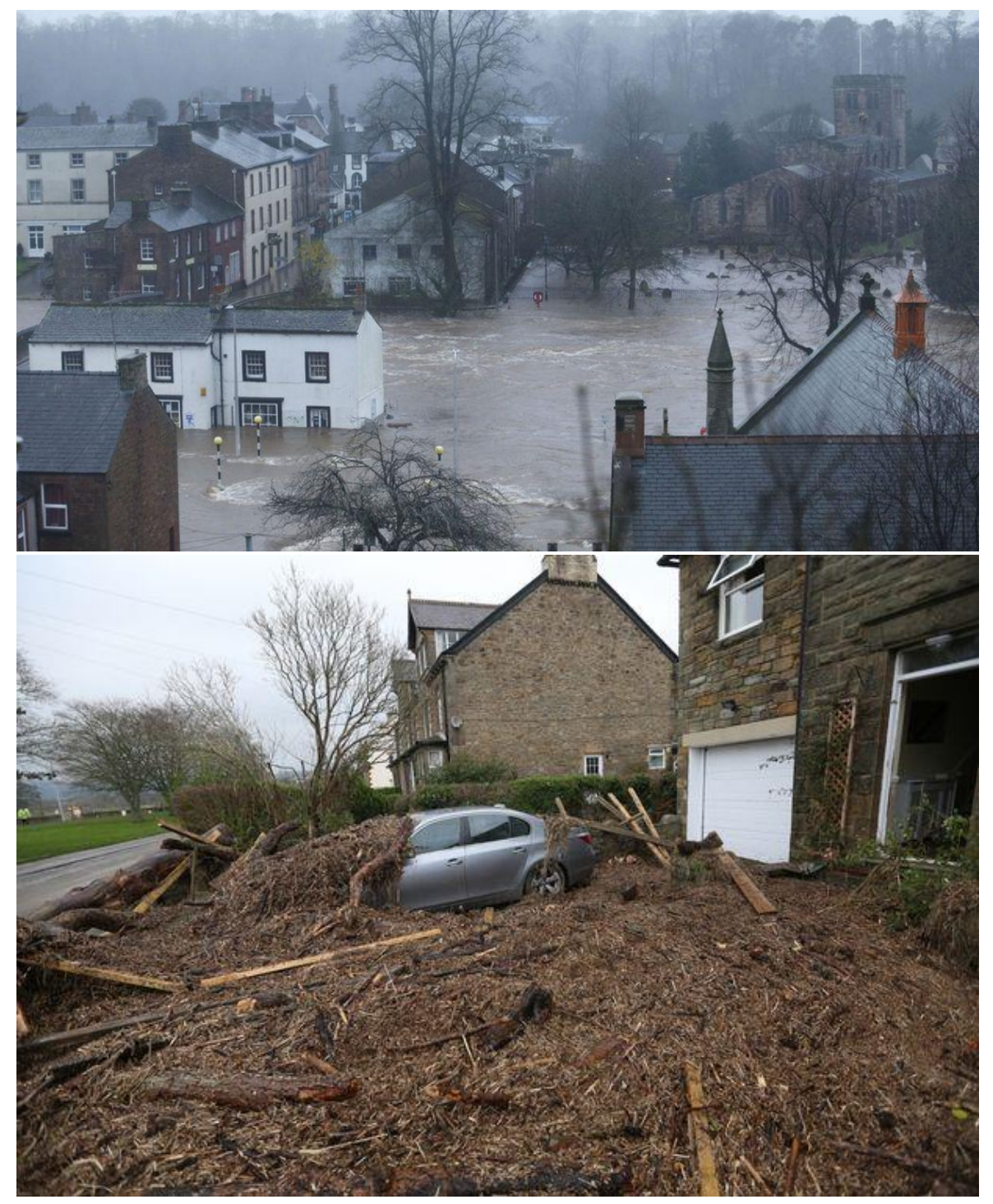

Figure 1. Views of recent UK flooding. A. Appleby, Cumbria under floodwaters during Storm Desmond (Photo credit: BBC News http://www.bbc.co.uk/news/uk-35014745 ). B. Corbridge, Northumberland, after Storm Desmond (Photo credit: Chronicle Live http://i1.chroniclelive.co.uk/incoming/article10562464.ece/ALTERNATES/s615b/JS78251465.jpg ). 


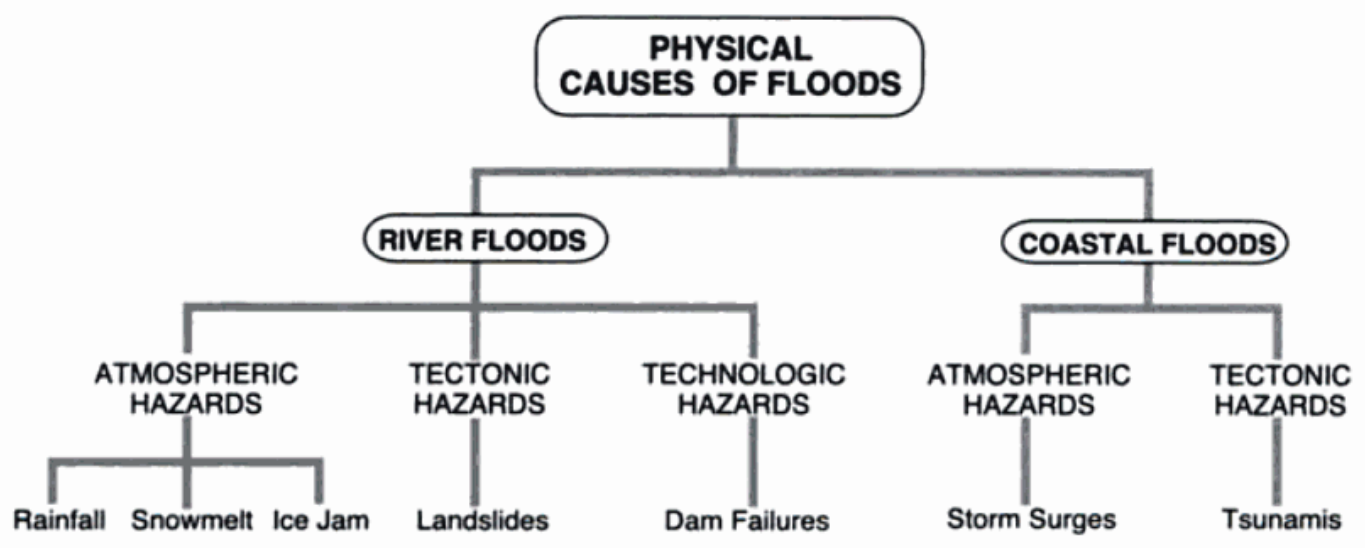

Figure 2. The physical causes of flooding (Reproduced from Smith, 2013).

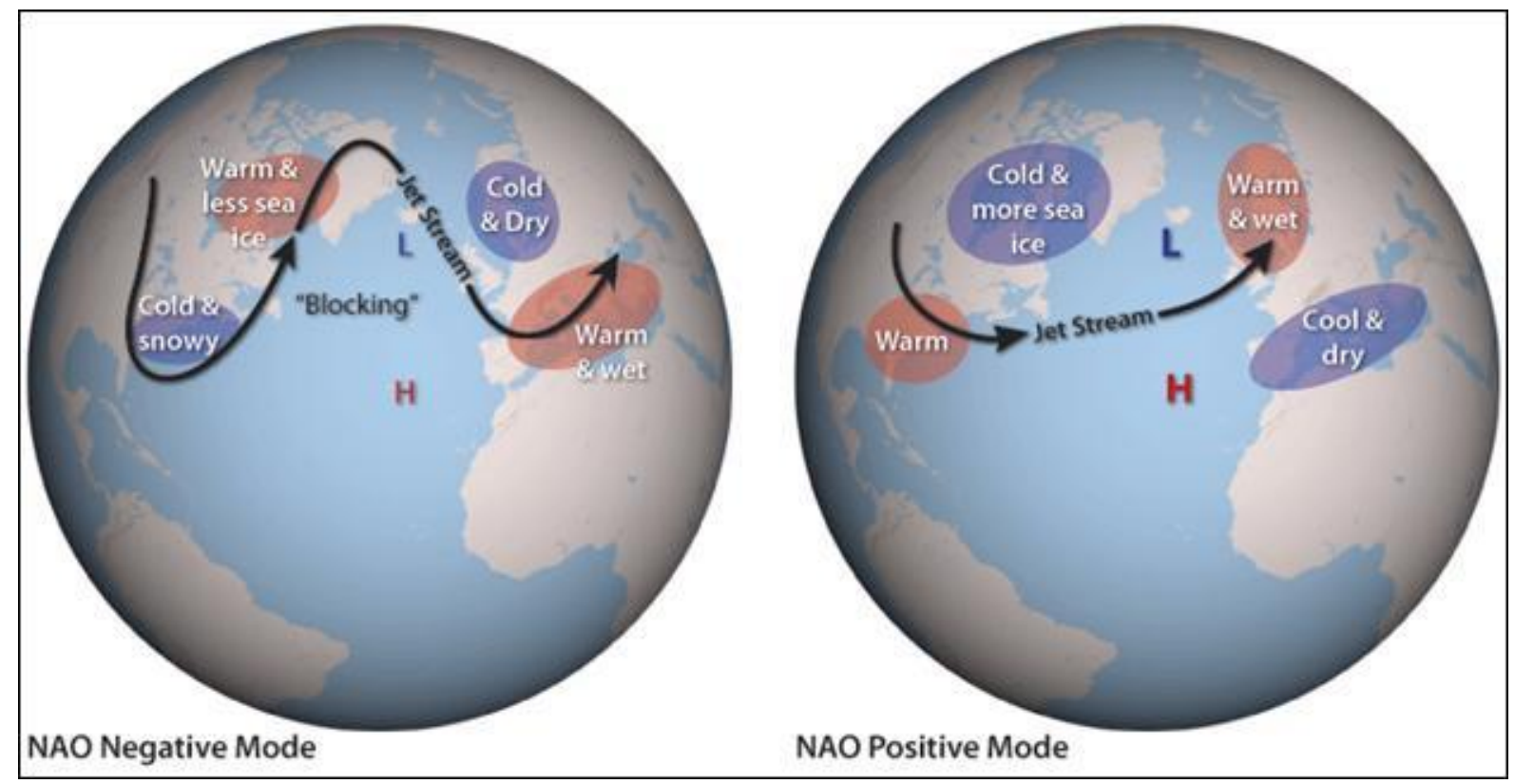

Figure 3. The North Atlantic Oscillation shown in its negative and positive modes (Source: www.climate.gov). 


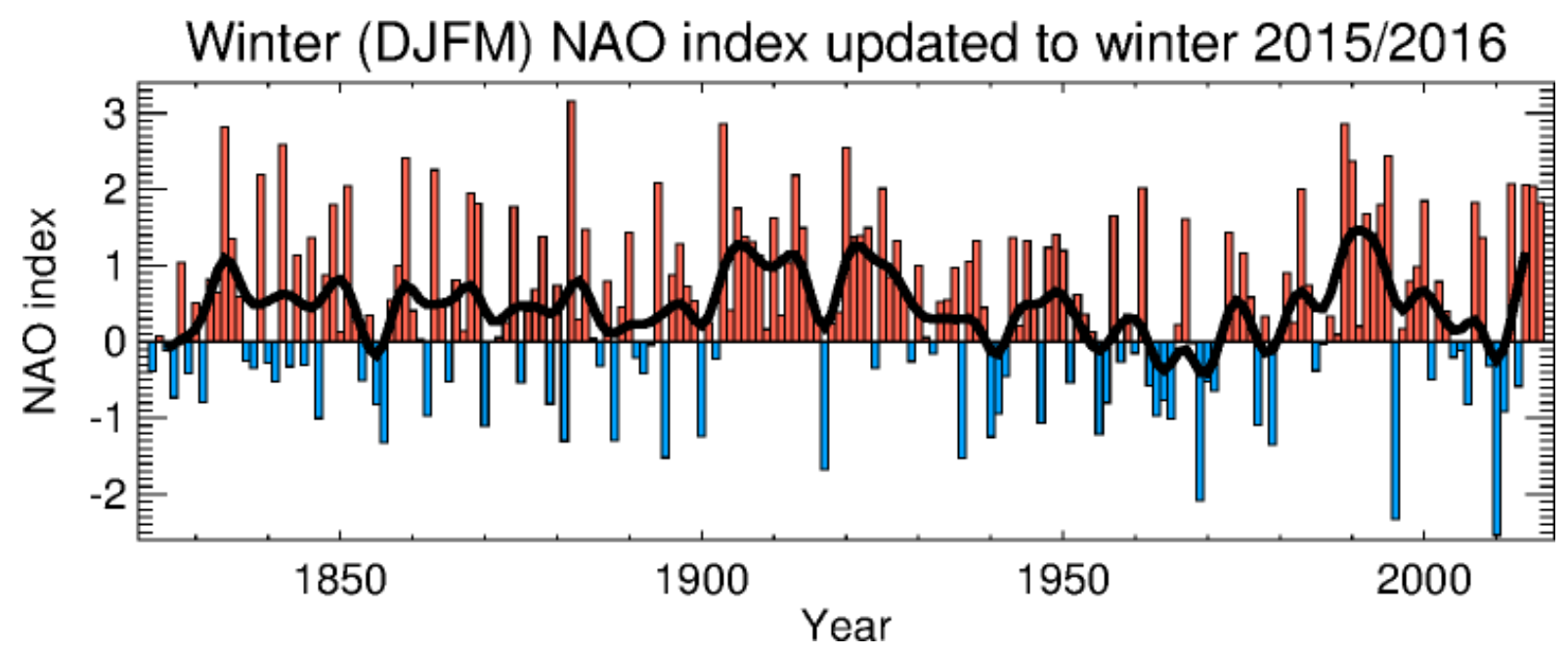

Figure 4. A time series of the North Atlantic Oscillation Index showing winter negative and positive modes, extended back to 1823 using instrumented data by Jones et al. (1997), and updated to the winter of 2015/16 by Osborne (Source: https://crudata.uea.ac.uk/ timo/datapages/naoi.htm ).

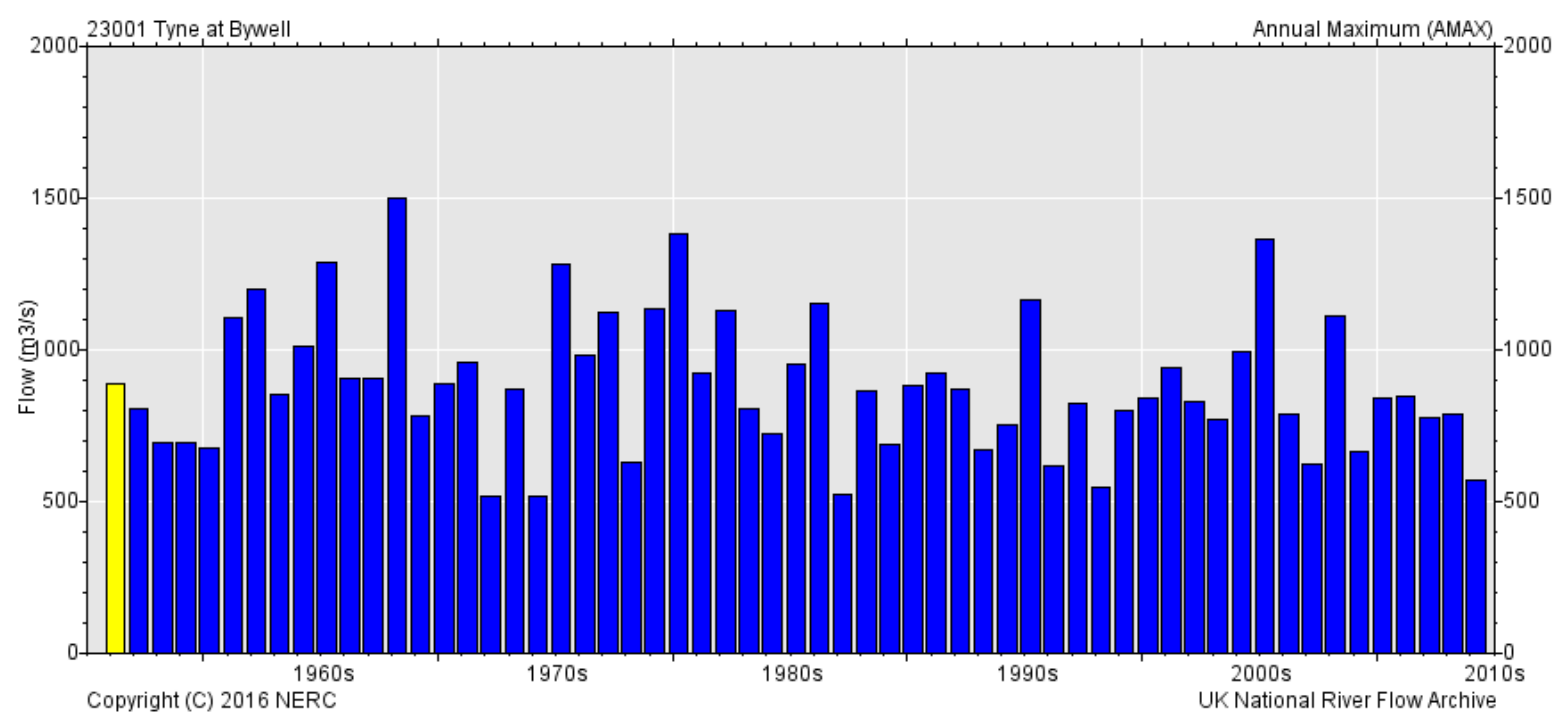

Figure 5. An example of the extent of the gauged record of flooding in the UK: the Annual Maximum peak flow for the River Tyne recorded at Bywell, between1956 and present (Source: http://nrfa.ceh.ac.uk/data/station/peakflow/23001). 

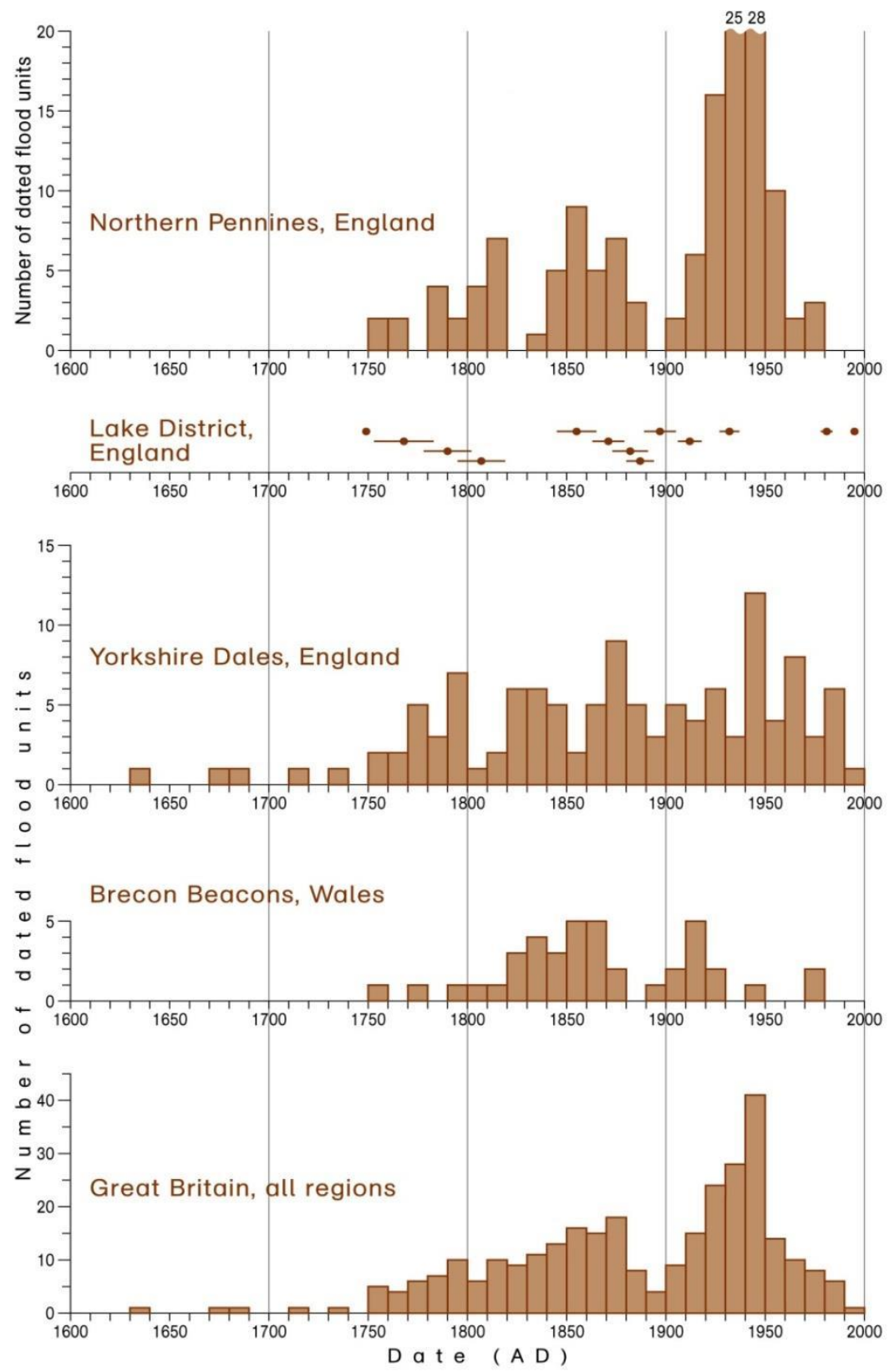

Figure 6. Dated flood units from sites in upland Britain (Taken from Macklin and Rumsby, 2007). 